PROF. MARTHA LAPPAS (Orcid ID : 0000-0002-4744-6929)

Received Date : 02-Nov-2016

Revised Date : 06-Feb-2017

Accepted Date : 16-Feb-2017

Article type : Original article

\title{
TRADD, TRAF2, RIP1 and TAK1 are required for TNF- $\alpha$-induced pro-labour mediators in human primary myometrial cells
}

Running Title: TNF- $\alpha$ signalling in human myometrium

Ratana Lim ${ }^{1,2}$, Gillian Barker ${ }^{1,2}$ and Martha Lappas ${ }^{1,2}$

${ }^{1}$ Obstetrics, Nutrition and Endocrinology Group, Department of Obstetrics and Gynaecology, University of Melbourne, Victoria, Australia

${ }^{2}$ Mercy Perinatal Research Centre, Mercy Hospital for Women, Heidelberg, Victoria, Australia

\section{Correspondence and Reprint Requests to:}

Associate Professor Martha Lappas

Department of Obstetrics and Gynaecology, University of Melbourne

Mercy Hospital for Women, Level 4/163 Studley Road

Heidelberg, 3084, Victoria, Australia

Ph: 61-3-8458 4370; Fax: 61-3-8458 4380

E-mail: mlappas@unimelb.edu.au

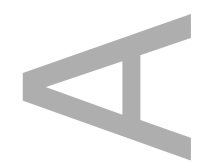

This is the author manuscript accepted for publication and has undergone full peer review but has not been through the copyediting, typesetting, pagination and proofreading process, which may lead to differences between this version and the Version of Record. Please cite this article as doi: $\underline{10.1111 / a j i .12664}$

This article is protected by copyright. All rights reserved 
3 Problem: TNF- $\alpha$ plays a central role in the processes of human labour and delivery. This study sought to determine the role of the adaptor proteins TNFR1-associated death domain protein (TRADD), TNF receptor-associated factor 2 (TRAF2), receptor interacting protein 1 (RIP1) and transforming growth factor beta-activated kinase 1 (TAK1) in TNF- $\alpha$-induced formation of prolabour mediators.

8 Method of Study: Human primary myometrial cells were transfected with siRNA against TRADD 9 (siTRADD), TRAF2 (siTRAF2), RIP1 (siRIP1) or TAK1 (siTAK1), treated with TNF- $\alpha$, and 10 assayed for pro-inflammatory mediators expression.

11 Results: siTRADD, siTRAF2, siRIP1 and siTAK1 significantly decreased TNF- $\alpha$-induced IL- $1 \alpha$, 12 IL-1 $\beta$, IL-6, IL-8, MCP-1 mRNA expression and release of IL-6, IL-8 and MCP-1; and 13 cyclooxygenase (COX)-2 expression and release of prostaglandin $\mathrm{PGF}_{2 \alpha}$. There was a significant attenuation of TNF- $\alpha$-induced expression of adhesion molecules ICAM-1 and VCAM-1 mRNA with siTRADD, siTRAF2 or siRIP1. siTRADD and siRIP1 significantly attenuated TNF- $\alpha$-induced MMP-9 mRNA expression and release and nuclear factor $\kappa \mathrm{B}(\mathrm{NF}-\kappa \mathrm{B})$ transcriptional activity.

There was a significant increase in TNF- $\alpha$-induced sVCAM-1 release, MMP-9 mRNA expression

19 Conclusions: TRADD, TRAF2, RIP1 and TAK1 are involved in TNF- $\alpha$ signalling in human myometrium. Further studies are required to determine if inhibition of these proteins can prevent 21 preterm birth.

\section{INTRODUCTION}

Preterm birth occurs in approximately $10 \%$ of all births worldwide ${ }^{1}$. The ensuing prematurity of the newborns is the biggest contributing factor to perinatal morbidity and mortality ${ }^{2}$. Many children born preterm will suffer life-long neurological and developmental problems. In addition to emotional stress on families faced with preterm birth and having a newborn in intensive care, the financial costs for individuals and health care systems are enormous. There are no therapeutics that can reduce the high incidence of preterm birth and prevent its adverse outcomes. Thus, a greater understanding of the mechanisms regulating term and preterm parturition are required.

TNF- $\alpha$, released from leukocytes invading the intrauterine cavity during parturition ${ }^{3}$, plays an 34 important role in the processes of human labour and delivery. Studies in humans demonstrated higher amniotic fluid concentrations of TNF- $\alpha$ in patients who subsequently delivered preterm than 
in patients who delivered at term ${ }^{4}$. Likewise, high concentrations of TNF- $\alpha$ in the vaginal or cervical secretions in women with symptoms of preterm labour are associated with early preterm delivery ${ }^{5}$. Elevated TNF- $\alpha$ levels are also detected in amniotic fluid during pregnancies complicated by infection and preterm delivery in humans ${ }^{6}$. In non-human primates, injection of the amniotic cavity with TNF- $\alpha$ induces preterm labour ${ }^{7}$. In vivo, intraamniotic infusion of TNF- $\alpha$ is associated with significant elevations in pro-inflammatory cytokines, chemokines, prostaglandins, MMP-9 and leukocytes in amniotic fluid ${ }^{7}$. Likewise, in vitro, TNF- $\alpha$ can amplify or initiate the process of parturition by further increasing cytokine production ${ }^{8}$; promoting the synthesis of cyclooxygenase $(\mathrm{COX})-2$, prostaglandin $\mathrm{F}_{2 \alpha}\left(\mathrm{PGF}_{2 \alpha}\right)$, and the $\mathrm{PGF}_{2 \alpha}$ receptor $(\mathrm{FP}) \stackrel{9-11}{ }$ which are important regulators of myometrial contractility; activating the extracellular matrix remodelling enzyme matrix metalloproteinase (MMP)-9 $\frac{12}{\text {; }}$ and induce the expression of adhesion molecules $\underline{11}$ that can further recruit leukocytes into the uterus. Therefore, understanding the intermediates involved in the TNF- $\alpha$ signalling pathway is critical for the development of therapeutics to manage or prevent preterm birth.

The canonical (or classical) NF- $\mathrm{B}$ pathway has a major role in the control of innate immunity and inflammation $\frac{13}{1}$. The NF- $\kappa$ B pathway also plays a central role in the terminal processes of human labour and delivery ${ }^{14}$. In human gestational tissue, $\mathrm{NF}-\kappa \mathrm{B}$ is activated by a broad range of stimuli including TNF- $\alpha$. Following stimulation, I $\kappa$ B- $\alpha$, which typically holds the NF- $\kappa$ B RelA-p50 heterodimer in the cytoplasm, is phosphorylated by IאB kinase (IKK), leading to its rapid degradation. This allows free NF- $\kappa \mathrm{B}$ to translocate to the nucleus where it binds to $\kappa \mathrm{B}$ sites, leading to gene transcription. In human myometrium, NF- $\mathrm{BB}$ has been shown to control the transcription of a number of pro-labour genes including IL-6, IL-8, COX-2 and MMP-9.

The adaptor proteins TNFR1-associated death domain protein (TRADD), TNF receptor-associated factor 2 (TRAF2), cellular inhibitor of apoptosis proteins 1 and 2 (cIAP1 and cIAP2), receptor interacting protein 1 (RIP1) and transforming growth factor beta-activated kinase 1 (TAK1) have emerged as critical signalling intermediates of TNF- $\alpha$-induced inflammation $\frac{15-18}{}$. TNF- $\alpha$ binds to its cell surface receptor TNFR1 which leads to the recruitment of the intracellular death domain (DD)-containing adaptor TRADD. Recruitment of TRADD can i) promote the association of the TNFR1 complex with Fas-associated DD (FADD) which induces caspase activation and cell death; or ii) recruit TRAF2, RIP1, cIAPs and TAK1, which trigger NF- $\kappa \mathrm{B}$ activation and resultant proinflammatory responses $\frac{19}{}$. 
We have previously shown cIAP1 and cIAP2 are required for TNF- $\alpha$-induced expression of prolabour mediators in human myometrium ${ }^{9}$. The role, however, of TRADD, TRAF2, RIP1 and TAK1 in the genesis of pro-inflammatory and pro-labour mediators induced by TNF- $\alpha$ in myometrium is not known. Thus, the aim of this study was to use siRNA to determine if TRADD, TRAF2, RIP1 and TAK1 are involved in TNF- $\alpha$-induced expression and secretion of proinflammatory cytokines; COX-2 expression and subsequent prostaglandin release; expression and secretion of adhesion molecules ICAM-1 and VCAM-1; and expression of the ECM remodelling

MATERIALS AND METHODS

\section{Tissue collection}

The Research Ethics Committee of Mercy Hospital for Women approved this study. Written, informed consent was obtained from all participating women. All myometrial samples were obtained from women who delivered healthy, singleton infants at term (37-41 weeks gestation) undergoing elective Caesarean section in the absence of labour. All tissues were brought to the research laboratory and processed within 15 mins of the Caesarean delivery. Women with any underlying medical conditions such as diabetes, asthma, polycystic ovary syndrome, preeclampsia and macrovascular complications were excluded. Additionally, women with multiple pregnancies,

\section{Primary myometrial cell culture}

92 Cells were isolated and cultured as previously described $\stackrel{11}{ }$. Briefly, myometrium was minced and 93 digested for 1 h in Dulbecco's Modified Eagle's Medium/Nutrient Mixture F-12 Ham (DMEM/F12) with $3 \mathrm{mg} / \mathrm{ml}$ type 1 collagenase (Worthington Biochemical, Freehold, USA) and $80 \mu \mathrm{g} / \mathrm{ml}$ DNase 1 (Roche Diagnostics, Castle Hill, Australia) at $37^{\circ} \mathrm{C}$. Cells were centrifuged at $400 \times \mathrm{g}$ for $10 \mathrm{~min}$ and grown in DMEM/F-12 enriched with 10\% heat-inactivated FCS (containing $100 \mathrm{U} / \mathrm{ml}$

\section{TRADD, TRAF2, RIP1 and TAK1 siRNA transfection}

100 Transfection of primary myometrial cells was performed as we have previously described 11 .

101 Briefly, cells at approximately 50\% confluence were transfected using Lipofectamine 3000 according to manufacturer's guidelines (Life Technologies; Mulgrave, Victoria, Australia). TRADD siRNA (siTRADD), TRAF2 siRNA (siTRAF2), TAK1 siRNA (siTAK1) and negative control siRNA (siCONT) were obtained from Ambion (Thermo Fisher Scientific; Scoresby, Vic, Australia). 
RIP1 siRNA (siRIP1) was obtained from Santa Cruz Biotechnology (Santa Cruz Biotechnology, Santa Cruz, CA, USA). Cells were transfected with $50 \mathrm{nM}$ siRNA (TRADD, TRAF2 or TAK1) or $100 \mathrm{nM}$ siRNA (RIP1) in DMEM/F-12 for $48 \mathrm{~h}$ followed by treatment with or without $10 \mathrm{ng} / \mathrm{ml}$ TNF- $\alpha$ (PeproTech; Rocky Hill, NJ, USA) for $24 \mathrm{~h}$. Cells were collected and stored at $-80^{\circ} \mathrm{C}$ until assayed for mRNA expression by qRT-PCR as detailed below. Media was collected and stored at $-80^{\circ} \mathrm{C}$ until assayed for cytokine and prostaglandin release as detailed below. Cell viability was

111 assessed by the 3-(4,5-dimethyl-2-thiazolyl)-2,5-diphenyl-2H-tetrazolium bromide (MTT)

112 proliferation assay as we have previously described ${ }^{11}$. The response to TNF- $\alpha$ between patients

113 varied greatly, as we have previously reported 11 . Thus, data is presented as fold change in

114 expression relative to the expression level in TNF- $\alpha$-stimulated siCONT transfected cells, which was set at 1. Experiments were performed from myometrium obtained from five patients.

NF-кB luciferase assay

118 A luciferase assay was also used to determine the possible interactions between TRADD, TRAF2,

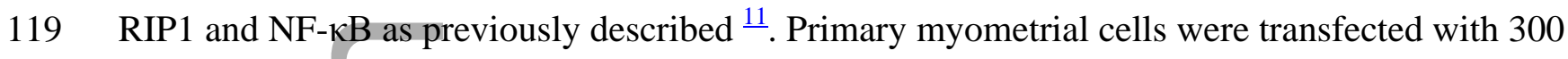
$120 \mathrm{ng} / \mathrm{ml} \mathrm{NF- \kappa B}$ reporter construct (Qiagen; Chadstone Centre, Vic, Australia) using FuGENE HD 121 transfection reagent (Promega; Alexandria NSW, Australia). After $6 \mathrm{~h}$, cells were transfected with $50 \mathrm{nM}$ siRNA (TRADD, TRAF2 or TAK1) or $100 \mathrm{nM}$ of siRIP1 or siCONT (as detailed above) for $48 \mathrm{~h}$. The medium was then replaced with DMEM/F-12 (containing 0.5\% BSA), with or without 10 $\mathrm{ng} / \mathrm{ml} \mathrm{TNF}-\alpha$ and the cells incubated at $37^{\circ} \mathrm{C}$ for an additional $20 \mathrm{~h}$. After final incubation, cells were harvested in lysis buffer, and luminescence activity was measured using a Luciferase Reporter Assay Kit (Life Research; Scoresby, Vic, Australia) and Renilla Luciferase Flash Assay kit (Thermo Fisher Scientific; Scoresby, Vic, Australia) as instructed. The ratio of the firefly luciferase level to the Renilla luciferase level was determined and the results are expressed as a ratio of normalised luciferase activity. The experiments were performed from myometrium obtained from five patients.

\section{RNA extraction and qRT-PCR}

133 RNA extractions and qRT-PCR was performed as previously described $\stackrel{11}{ }$. RNA quality and 134 integrity were measured using a NanoDrop ND1000 and determined via the $\mathrm{A}_{260} / \mathrm{A}_{280}$ ratio. RNA $135(0.2 \mu \mathrm{g})$ was converted to cDNA using the high-capacity cDNA reverse transcription kit according 136 to the manufacturer's instructions (Applied Biosystems; Waltham, MA, USA). RT-PCR was 137 performed using the CFX384 Real-Time PCR detection system (Bio-Rad Laboratories; Gladesville, 138 NSW, Australia) using $100 \mathrm{nM}$ of pre-designed and validated QuantiTect primers (primer 139 sequences not available) (Qiagen; Chadstone Centre, Vic, Australia). Average gene Ct values were 
normalised against two housekeeping genes ( $\beta 2$-Microglobulin (B2M) and succinate dehydrogenase complex subunit A (SDHA)). Fold differences were determined using the comparative Ct method.

\section{Enzyme immunoassays}

Assessment of cytokine and chemokine release of IL-6 and IL-8 was performed using the CytoSet $^{\mathrm{TM}}$ sandwich ELISA according to the manufacturer's instructions (Life Technologies; Mulgrave, Vic, Australia). The release of MCP-1, sICAM-1 and sVCAM-1 was performed by sandwich ELISA from R\&D Systems (Minneapolis, MN, USA) according to the manufacturer's instructions. The release of $\mathrm{PGF}_{2 \alpha}$ into the incubation medium was assayed using a commercially available competitive enzyme immunoassay kit according to the manufacturer's specifications (Kookaburra Kits from Sapphire Bioscience, NSW, Australia). The interassay and intraassay coefficients of variation for all assays were less than $10 \%$.

\section{Gelatin zymography}

Incubation media was also collected and assessment of MMP-9 was performed by gelatin zymography as previously described ${ }^{20}$. Proteolytic activity was visualized as clear zones of lysis on a blue background of undigested gelatin. Gels were scanned using a ChemiDoc XRS system (BioRad Laboratories; Gladesville, NSW, Australia), inverted, and densitometry performed using using Quantity One image analysis software (Bio-Rad Laboratories; Gladesville, NSW, Australia). Fold change was calculated relative to TNF- $\alpha$, which was set at 1 .

\section{Statistical analysis}

All statistical analyses were undertaken using GraphPad Prism (GraphPad Software, La Jolla, CA, USA). The homogeneity of data was assessed by the Bartlett's test, and when significant, the data were logarithmically transformed before further analysis using a one-way ANOVA (with LSD posthoc testing to discriminate among the means). Statistical significance was ascribed to a $P$ value $<0.05$. Data were expressed as mean \pm SEM.

\section{RESULTS}

\section{Effect of siTRADD, siTRAF2, siRIP1 and siTAK1 on pro-inflammatory cytokines and}

\section{chemokines}

The efficacy of siRNA transfection is demonstrated in Supplementary Figure 1. When compared to siCONT transfected cells, there was $~ 85 \%$ decrease in TRADD mRNA with siTRADD; $60 \%$ decrease in TRAF2 mRNA expression with siTRAF2; 70\% decrease in RIP1 mRNA expression 
with siRIP1; and 90\% decrease in TAK1 mRNA expression with siTAK1. A MTT cell viability assay showed no difference in absorbance between cells transfected with siCONT or siTRADD, siTRAF2, siRIP1 or siTAK1 (Supplementary Figure 1).

For subsequent experiments, after siRNA transfection, cells were treated with TNF- $\alpha$. As expected, in siCONT transfected cells, TNF- $\alpha$ significantly increased IL-6, IL-8 and MCP-1 mRNA expression and secretion (Figure 1). This increase was significantly decreased in siTRADD (Figures 1A-F), siTRAF2 (Figures 1A-F), siRIP1 (Figures 1G-L) or siTAK1 (Figures 1M-R) transfected cells. In addition, IL- $1 \alpha$ and IL- $1 \beta$ mRNA expression was also increased by TNF- $\alpha$ treatment in siCONT transfected cells. The effect of siTRADD, siTRAF2, siRIP1 or siTAK1 was a significant decrease in IL-1 $\alpha$ and IL-1 $\beta$ mRNA expression (Table I). As we have previously reported, IL- $1 \alpha$ and IL-1 $\beta$ levels are not detectable in the incubation media from human primary myometrial cells $\underline{10}$ and thus not assessed.

\section{Effect of siTRADD, siTRAF2, siRIP1 and siTAK1 on COX-2-prostaglandin pathway}

Treatment of primary myometrial cells with TNF- $\alpha$ significantly increased COX-2 (Figures 2A,D,G) and FP(Figures 2B,E,H) mRNA expression, and subsequent $\mathrm{PGF}_{2 \alpha}$ release (Figures 2C,F,I). The effect of siTRADD (Figures 2A-C), siTRAF2 (Figures 2A-C), siRIP (Figures 2D-F) or siTAK1 (Figures 2G-I) was a significantly attenuation of TNF- $\alpha$-induced COX-2 and FP mRNA expression and $\mathrm{PGF}_{2 \alpha}$ release.

\section{Effect of siTRADD, siTRAF2, siRIP1 and siTAK1 on adhesion molecules} As expected, ICAM-1 and VCAM-1 mRNA expression, and SICAM-1 and sVCAM-1 were significantly increased in siCONT cells incubated with TNF- $\alpha$ (Figure 3 ). TNF- $\alpha$-induced ICAM-1 mRNA expression and sICAM-1 release was significantly attenuated in cells transfected with siTRADD (Figures 3A,B), siTRAF2 (Figures 3A,B), siRIP1 (Figures 3E,F), or siTAK1 (Figures 3I,J). TNF- $\alpha$-induced VCAM-1 mRNA expression was significantly suppressed by siTRADD (Figures 3C), siTRAF2 (Figures 3C), siRIP1 (Figures 3G), or siTAK1 (Figures 3K). Further, TNF$\alpha$-induced sVCAM-1 release was also significantly decreased by siTRADD (Figure 3D) or siRIP1 (Figure 3H). There was no effect of siTRAF2 on TNF- $\alpha$-induced sVCAM-1 release (Figure 3D), while siTAK1 significantly augmented TNF- $\alpha$-induced sVCAM-1 release (Figure 3L).

\section{Effect of siTRADD, siTRAF2, siRIP1 and siTAK1 on MMP-9}

Figure 4 demonstrates the effect of siTRADD, siTRAF2, siRIP1 and siTAK1 on the expression of the ECM degrading and remodelling enzyme MMP-9. In siCONT transfected cells, TNF- $\alpha$ 
210 significantly increased MMP-9 mRNA expression (Figures 4A,C,E) and pro MMP-9 secretion

211 (Figures 4B,D,F). The effect of siTRADD (Figure 4A), siTRAF2 (Figure 4A) or siRIP1 (Figure 4C) 212 was a significant suppression of TNF- $\alpha$-induced MMP-9 mRNA. In addition, siTRADD (Figure 4B 213 and siRIP1 (Figure 4D) also significantly reduced TNF- $\alpha$-induced pro MMP-9 secretion. There 214 was, however, no effect of siTRAF2 on pro MMP-9 secretion (Figure 4B). Unexpectedly, siTAK1 215 significantly augmented MMP-9 mRNA expression (Figure 4E) and pro MMP-9 secretion (Figure 216 4F).

\section{Effect of siTRADD, siTRAF2, siRIP1 and siTAK1 on NF-кB activation}

The final aim of this study was to investigate if TRADD, TRAF2, RIP1 and TAK1 elicits their effects via interfering with NF- $\kappa \mathrm{B}$ activation. As expected, TNF- $\alpha$ significantly increased NF- $\kappa \mathrm{B}$ transcriptional activity (Figure 5). The result of siTRADD (Figure 5A) and siRIP1 (Figure 5C) was a significant suppression of TNF- $\alpha$ induced NF- $\kappa B$ activation. On the other hand, there was no effect of siTRAF2 on TNF- $\alpha$ induced NF- $\kappa$ B activation (Figure 5B) while siTAK1 further

\section{DISCUSSION}

The novel findings of this study are that in human myometrium, TRADD, TRAF2, RIP1 and TAK1 are required for TNF- $\alpha$-induced expression of pro-labour mediators. Specifically, loss-of-function studies demonstrated that in the absence of TRADD, TRAF2, RIP1 and TAK1, the expression and or secretion of pro-inflammatory cytokines, chemokines, prostanoids and cell adhesion molecules to TNF- $\alpha$ was, for the most part, significantly blunted. These findings are in concordance with studies in non-gestational tissues $\stackrel{15-18}{\text {. }}$.

TNF- $\alpha$ exists in two biologically active forms, a membrane-bound form (mTNF- $\alpha$ ) and a soluble form (sTNF- $\alpha$ ), which bind to their cognate receptors TNFR1 and TNFR2. Engagement of TNFR1 rapidly leads to the assembly of a membrane associated protein complex (termed complex I) consisting of TRADD, TRAF2 and RIP1. Activation of TNFR1 recruits the adapter protein TRADD and the serine-threonine kinase RIP1. TRADD can further recruit the adapter protein TRAF2 via its $\mathrm{N}$-terminal TRAF-binding domain. Complex 1 can activate numerous signalling pathways to induce inflammation, activate both pro-apoptotic and anti-apoptotic pathways or promote cell growth ${ }^{21}$. Pro-inflammatory signalling, however, is the most favoured pathway through the recruitment of TAK1 and the IKK complex resulting in NF- $\mathrm{BB}$ activation. Complex 1 
also activates activator protein (AP)-1 and mitogen-activated protein kinase (MAPK) signalling by recruitment of TAK1.

In this study, knockdown of TRADD, TRAF2, RIP1 or TAK1 in primary myometrial cells significantly suppressed TNF- $\alpha$-induced expression and secretion of pro-inflammatory cytokines and chemokines. These findings are of significance given the central role of pro-inflammatory cytokines and chemokines in the processes of labour and delivery, both at term and preterm $-\stackrel{8}{\text {. }}$ Concomitant with increased macrophage and neutrophil infiltrate ${ }^{3}$, myometrium of healthy labouring women is associated with an upregulation of mRNA expression of numerous proinflammatory cytokines (e.g. IL-1 $\beta$, IL-6, TNF- $\alpha$ ) and chemokines (e.g. IL-8, MCP-1) $\stackrel{22}{\text {. Pro- }}$ inflammatory cytokines can then further induce: (i) cytokine release through positive feed forward mechanism; (ii) the expression of adhesion molecules; (iii) COX-2 expression and subsequent prostaglandin production, and (iv) ECM matrix remodelling enzymes such as MMP-9. Collectively, these events facilitate human labour and delivery.

Prostaglandins play an important role in the regulation of parturition. COX-2 is the rate limiting enzyme involved in the conversion of arachidonic acid into prostaglandins. Increased expression of COX-2 observed in myometrium before labour onset ${ }^{23}$ is responsible for the increased synthesis of prostaglandins observed during labour. $\mathrm{PGF}_{2 \alpha}$ is an important mediator of uterine contractility $\stackrel{24}{ }$, exerting its actions via its receptor, $\mathrm{FP} \underline{25}$ whose expression is also increased at term labour in myometrium $\stackrel{26}{ }$. TNF- $\alpha$ has been shown to induce the expression of COX-2 and FP $\stackrel{9-11}{2}$ and stimulate the synthesis of prostanoids $\stackrel{9}{10}$ in human myometrial cells. In this study, we show that TRADD, TRAF2, RIP1 or TAK1 are required for TNF- $\alpha$-induced COX-2 and FP mRNA expression and resultant prostaglandin secretion.

The expression of the cell adhesion molecules such as ICAM-1 and VCAM-1 are increased in human cervix and myometrium during pregnancy and parturition 27 , 28 ; in part due to the expression of infiltrating leukocytes in the myometrium, cervix and fetal membranes at parturition $\underline{3}, \underline{29}$. These adhesion molecules can then attract neutrophils, macrophages and T cells to invade these tissues. Cytokines, induced by stretch, play an essential role in leukocyte migration $\stackrel{30}{ }$. We have previously shown that TNF- $\alpha$ can induce ICAM-1, VCAM-1 and MMP-9 mRNA expression and secretion from human myometrial cells $\frac{11}{}$. TNF- $\alpha$ can also induce the expression of MMP-9 $\stackrel{11}{\underline{31}}$ which is involved in tissue remodelling of human myometrium during labour. In this study, we demonstrated a requirement for TRADD, TRAF2 and RIP1 in TNF- $\alpha$-induced ICAM-1, VCAM-1 and MMP-9 expression and/or secretion in primary myometrial cells. Of note, while VCAM-1 and MMP-9 
mRNA expression were decreased by siTRAF2, the secretion of sVCAM-1 and pro MMP-9 were

281 unchanged; possibly due to post-translation modifications. Furthermore, and in contrast to

282 siTRADD, siTRAF2 or siRIP1, siTAK1 significantly augmented MMP-9 mRNA expression and 283 pro MMP-9 secretion. The reason for the increase in MMP-9 is not known; but may-it may be due 284 to activation of pathways downstream of TAK1 (discussed below).

Mice with genetic knockout of TRADD, TRAF2, RIP1 or TAK1 have clearly demonstrated their

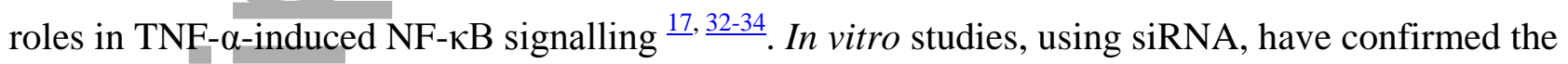
288 role of these proteins in TNF- $\alpha$ signalling in a numbers of different cells. For example, TRADD, 289 TRAF2 or TAK1 are required for TNF- $\alpha$-induced NF- $\kappa B$ activation in mouse embryonic fibroblasts (MEFs) and RIP1-deficient Jurkat T cells are specifically defective in the activation of NF- $\kappa \mathrm{B}$ in response to TNF- $\alpha$ stimulation $\frac{15-18}{}$. In support, this study reports that TRADD and RIP1 are required for TNF- $\alpha$-induced NF- $\kappa$ B signalling in human myometrial cells. On the other hand, there was no effect of siTRAF2 on NF- $\kappa$ B transcriptional activity while NF- $\kappa$ B activity was increased by

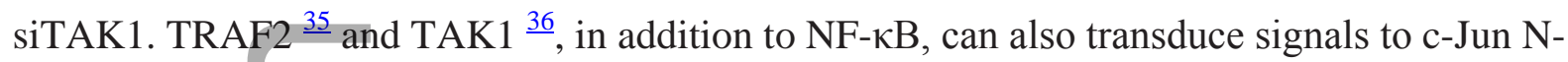
terminal kinase (JNK) and or p38 mitogen-activated protein kinase (p38 MAPK) of the mitogenactivated protein kinase (MAPK) pathway. Ultimately, other transcription factors downstream of p38 MAPK and JNK are activated including c-Jun and ATF2, resulting in the transcription of genes important for inflammatory and immune responses. p38 MAPK is involved in the regulation of proinflammatory and pro-labour mediators in fetal membranes $\stackrel{37}{~ w h i l e ~ s p e c i f i c ~ i n h i b i t o r s ~ o f ~ J N K ~}$

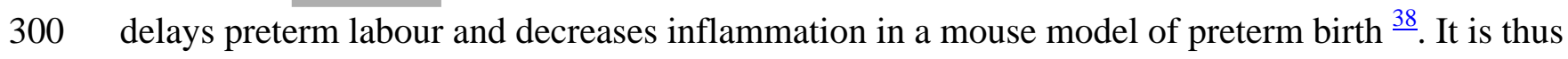
301 possible that TRAF2 and TAK1 regulate pro-inflammatory and pro-labour mediators in human myometrial cells via the p38 MAPK and/or JNK signalling pathways. Alternatively, only one time point was analysed in this study; it is possible that longer or shorter incubations are required with TNF- $\alpha$ to see an effect on NF- $\kappa$ B transcriptional activity. An avenue of further research, is the effect of siTRADD, siTRAF2, siRIP1 or siTAK1 on TNF- $\alpha-$ induced uterine contractions. The myometrium is maintained in a relatively quiescent state during pregnancy but is transformed into a contractile state at term labour. TNF- $\alpha$ has been shown to

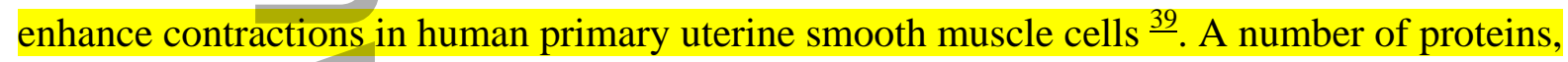
termed contractions associated proteins (CAPs), have been shown to be important in this process,

\section{1 induced FP mRNA expression, it would also be of interest to determine if they play a role in}

312 regulating myometrial contraptions in response to TNF- $\alpha$ treatment. 
314 In conclusion, for the first time, we report that TRADD, TRAF2, RIP1 and TAK1 play a role in the

315 regulating TNF- $\alpha$ signalling in human myometrium. These findings are of significance given the

316 central role of TNF- $\alpha$ in the processes of human labour and delivery. Further studies are required to

317 elucidate the significance of TRADD, TRAF2, RIP1 and TAK1 in human labour and delivery, and

318 whether inhibition of these proteins may be able to prevent preterm birth. Notably, inhibition of

319 TAK1 has been reported to block inflammation in sheep. Specifically, intra-amniotic treatment with

320 the TAK1 inhibitor 5z-7-oxozeaeno reduced amniotic fluid levels of $\mathrm{PGE}_{2}$ and fetal membrane

321 leukocyte infiltration induced by the bacterial product LPS $\underline{40}$.

\section{ACKNOWLEDGEMENTS}

324 The following are gratefully acknowledged: the clinical Research Midwives Genevieve

325 Christophers, Gabrielle Pell, and Rachel Murdoch for sample collection; and the Obstetrics and 326 Midwifery staff of the Mercy Hospital for Women for their co-operation.

\section{FUNDING}

329 Associate Professor Martha Lappas is supported by a Career Development Fellowship from the 330 National Health and Medical Research Council (NHMRC; grant no. 1047025). Funding for this 331 study was provided by the NHMRC (grant no. 1058786), Norman Beischer Medical Research 332 Foundation and the Mercy Research Foundation.

\section{DISCLOSURE SUMMARY}

335 The authors have nothing to declare.

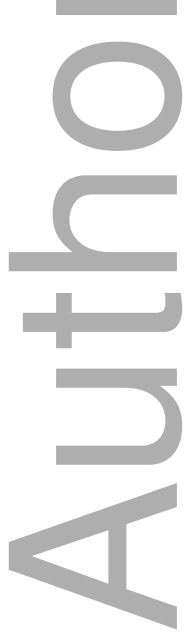




\section{REFERENCES}

1 Blencowe H, Cousens S, Oestergaard MZ, Chou D, Moller AB, Narwal R, Adler A, Vera Garcia C, Rohde S, Say L, Lawn JE: National, regional, and worldwide estimates of preterm birth rates in the year 2010 with time trends since 1990 for selected countries: a systematic analysis and implications. Lancet (London, England) 2012;379:2162-2172.

2 Beck S, Wojdyla D, Say L, Betran AP, Merialdi M, Requejo JH, Rubens C, Menon R, Van Look PF: The worldwide incidence of preterm birth: a systematic review of maternal mortality and morbidity. Bulletin of the World Health Organization 2010;88:31-38.

3 Osman I, Young A, Ledingham MA, Thomson AJ, Jordan F, Greer IA, Norman JE: Leukocyte density and pro-inflammatory cytokine expression in human fetal membranes, decidua, cervix and myometrium before and during labour at term. Mol Hum Reprod 2003;9:41-45.

4 Thomakos N, Daskalakis G, Papapanagiotou A, Papantoniou N, Mesogitis S, Antsaklis A: Amniotic fluid interleukin-6 and tumor necrosis factor-alpha at mid-trimester genetic amniocentesis: relationship to intra-amniotic microbial invasion and preterm delivery. European journal of obstetrics, gynecology, and reproductive biology 2010;148:147-151.

5 Inglis SR, Jeremias J, Kuno K, Lescale K, Peeper Q, Chervenak FA, Witkin SS: Detection of tumor necrosis factor-alpha, interleukin-6, and fetal fibronectin in the lower genital tract during pregnancy: relation to outcome. American journal of obstetrics and gynecology 1994;171:5-10.

6 Romero R, Mazor M, Sepulveda W, Avila C, Copeland D, Williams J: Tumor necrosis factor in preterm and term labor. American journal of obstetrics and gynecology 1992;166:1576-1587.

7 Sadowsky DW, Adams KM, Gravett MG, Witkin SS, Novy MJ: Preterm labor is induced by intraamniotic infusions of interleukin-1beta and tumor necrosis factor-alpha but not by interleukin- 6 or interleukin-8 in a nonhuman primate model. American journal of obstetrics and gynecology 2006;195:1578-1589.

8 Bowen JM, Chamley L, Keelan JA, Mitchell MD: Cytokines of the placenta and extraplacental membranes: roles and regulation during human pregnancy and parturition. Placenta 2002;23:257-273.

9 Lappas M: Cellular inhibitors of apoptosis proteins cIAP1 and cIAP2 are increased after labour in foetal membranes and myometrium and are essential for TNF-alpha-induced expression of pro-labour mediators. Am J Reprod Immunol 2015;73:313-329. 
10 Lappas M: Copper metabolism domain-containing 1 represses the mediators involved in the terminal effector pathways of human labour and delivery. Mol Hum Reprod 2016;22:299310.

11 Lim R, Tran HT, Liong S, Barker G, Lappas M: The transcription factor interferon regulatory factor-1 (IRF1) plays a key role in the terminal effector pathways of human preterm labor. Biol Reprod 2016;94:32.

12 Kumar D, Fung W, Moore RM, Pandey V, Fox J, Stetzer B, Mansour JM, Mercer BM, Redline RW, Moore JJ: Proinflammatory cytokines found in amniotic fluid induce collagen remodeling, apoptosis, and biophysical weakening of cultured human fetal membranes. Biol Reprod 2006;74:29-34.

13 Li QT, Verma IM: NF-kappa B regulation in the immune system. Nat Rev Immunol 2002;2:725-734.

14 Lappas M, Rice GE: The role and regulation of the nuclear factor kappa B signalling pathway in human labour. Placenta 2007;28:543-556.

15 Devin A, Cook A, Lin Y, Rodriguez Y, Kelliher M, Liu Z: The distinct roles of TRAF2 and RIP in IKK activation by TNF-R1: TRAF2 recruits IKK to TNF-R1 while RIP mediates IKK activation. Immunity 2000;12:419-429.

16 Ting AT, Pimentel-Muinos FX, Seed B: RIP mediates tumor necrosis factor receptor 1 activation of NF-kappaB but not Fas/APO-1-initiated apoptosis. The EMBO journal 1996;15:6189-6196.

17 Ermolaeva MA, Michallet MC, Papadopoulou N, Utermohlen O, Kranidioti K, Kollias G, Tschopp J, Pasparakis M: Function of TRADD in tumor necrosis factor receptor 1 signaling and in TRIF-dependent inflammatory responses. Nat Immunol 2008;9:1037-1046.

18 Shu HB, Takeuchi M, Goeddel DV: The tumor necrosis factor receptor 2 signal transducers TRAF2 and c-IAP1 are components of the tumor necrosis factor receptor 1 signaling complex. P Natl Acad Sci USA 1996;93:13973-13978.

19 Aggarwal BB: Signalling pathways of the TNF superfamily: A double-edged sword. Nat Rev Immunol 2003;3:745-756.

20 Lim R, Barker G, Lappas M: TREM-1 expression is increased in human placentas from severe early-onset preeclamptic pregnancies where it may be involved in syncytialization. Reproductive sciences (Thousand Oaks, Calif) 2014;21:562-572.

21 Wajant H, Pfizenmaier K, Scheurich P: Tumor necrosis factor signaling. Cell Death Differ 2003;10:45-65. 
22 Tattersall M, Engineer N, Khanjani S, Sooranna SR, Roberts VH, Grigsby PL, Liang Z, Myatt L, Johnson MR: Pro-labour myometrial gene expression: are preterm labour and term labour the same? Reproduction (Cambridge, England) 2008;135:569-579.

23 Slater D, Dennes W, Sawdy R, Allport V, Bennett P: Expression of cyclo-oxygenase types-1 and -2 in human fetal membranes throughout pregnancy. J Mol Endocrinol 1999;22:125130.

24 Bennett PR, Elder MG, Myatt L: The effects of lipoxygenase metabolites of arachidonic acid on human myometrial contractility. Prostaglandins 1987;33:837-844.

25 Senior J, Marshall K, Sangha R, Clayton JK: In vitro characterization of prostanoid receptors on human myometrium at term pregnancy. British Journal of Pharmacology 1993;108:501-506.

26 Brodt-Eppley J, Myatt L: Prostaglandin receptors in lower segment myometrium during gestation and labor. Obstetrics \& Gynecology 1999;93:89-93.

27 Ledingham MA, Thomson AJ, Jordan F, Young A, Crawford M, Norman JE: Cell adhesion molecule expression in the cervix and myometrium during pregnancy and parturition.

Obstetrics and gynecology 2001;97:235-242.

28 Winkler M, Kemp B, Fischer DC, Ruck P, Rath W: Expression of adhesion molecules in the lower uterine segment during term and preterm parturition. Microscopy research and technique 2003;60:430-444.

29 Thomson AJ, Telfer JF, Young A, Campbell S, Stewart CJ, Cameron IT, Greer IA, Norman JE: Leukocytes infiltrate the myometrium during human parturition: further evidence that labour is an inflammatory process. Human reproduction (Oxford, England) 1999;14:229236.

30 Lee YH, Shynlova O, Lye SJ: Stretch-induced human myometrial cytokines enhance immune cell recruitment via endothelial activation. Cellular \& Molecular Immunology 2015;12:231-242.

31 Roh CR, Oh WJ, Yoon BK, Lee JH: Up-regulation of matrix metalloproteinase-9 in human myometrium during labour: a cytokine-mediated process in uterine smooth muscle cells. Mol Hum Reprod 2000;6:96-102.

32 Kelliher MA, Grimm S, Ishida Y, Kuo F, Stanger BZ, Leder P: The death domain kinase RIP mediates the TNF-induced NF-kappaB signal. Immunity 1998;8:297-303.

33 Yeh WC, Shahinian A, Speiser D, Kraunus J, Billia F, Wakeham A, de la Pompa JL, Ferrick D, Hum B, Iscove N, Ohashi P, Rothe M, Goeddel DV, Mak TW: Early lethality, functional NF-kappaB activation, and increased sensitivity to TNF-induced cell death in TRAF2deficient mice. Immunity 1997;7:715-725. 
34 Shim JH, Xiao C, Paschal AE, Bailey ST, Rao P, Hayden MS, Lee KY, Bussey C, Steckel M, Tanaka N, Yamada G, Akira S, Matsumoto K, Ghosh S: TAK1, but not TAB1 or TAB2, plays an essential role in multiple signaling pathways in vivo. Genes \& development 2005;19:2668-2681.

35 Zhang L, Blackwell K, Shi Z, Habelhah H: The RING Domain of TRAF2 Plays an Essential Role in the Inhibition of TNF $\alpha$-Induced Cell Death but Not in the Activation of NF- $\kappa B$. Journal of Molecular Biology 2010;396:528-539.

36 Ninomiya-Tsuji J, Kishimoto K, Hiyama A, Inoue J, Cao Z, Matsumoto K: The kinase TAK1 can activate the NIK-I kappaB as well as the MAP kinase cascade in the IL-1 signalling pathway. Nature 1999;398:252-256.

37 Lappas M, Permezel M, Rice GE: Mitogen-activated protein kinase proteins regulate LPSstimulated release of pro-inflammatory cytokines and prostaglandins from human gestational tissues. Placenta 2007;28:936-945.

38 MacIntyre DA, Lee YS, Migale R, Herbert BR, Waddington SN, Peebles D, Hagberg H, Johnson MR, Bennett PR: Activator protein 1 is a key terminal mediator of inflammationinduced preterm labor in mice. FASEB journal : official publication of the Federation of American Societies for Experimental Biology 2014;28:2358-2368.

39 Fitzgibbon J, Morrison JJ, Smith TJ, O'Brien M: Modulation of human uterine smooth muscle cell collagen contractility by thrombin, Y-27632, TNF alpha and indomethacin. Reproductive biology and endocrinology : RB\&E 2009;7:2.

40 Ireland DJ, Kemp MW, Miura Y, Saito M, Newnham JP, Keelan JA: Intra-amniotic pharmacological blockade of inflammatory signalling pathways in an ovine chorioamnionitis model. Mol Hum Reprod 2015;21:479-489.

Table I. Effect of siTRADD, siTRAF2, siRIP and siTAK1 on IL-1 $\alpha$ and IL- $\beta$ mRNA expression

\begin{tabular}{|l|l|l|}
\hline & IL-1 $\alpha$ mRNA expression & IL-1 $\beta$ mRNA expression \\
\hline siCONT & $0.04 \pm 0.02^{*}$ & $0.00 \pm 0.00^{*}$ \\
\hline siCONT + TNF- $\alpha$ & $1.00 \pm 0.00$ & $1.00 \pm 0.00$ \\
\hline siTRADD + TNF- $\alpha$ & $0.50 \pm 0.16^{*}$ & $0.12 \pm 0.03 *$ \\
\hline siTRAF2 + TNF- $\alpha$ & $0.50 \pm 0.10^{*}$ & $0.03 \pm 0.02^{*}$ \\
\hline & & \\
\hline siCONT & $0.02 \pm 0.00^{*}$ & $0.00 \pm 0.00^{*}$ \\
\hline
\end{tabular}

This article is protected by copyright. All rights reserved 


\begin{tabular}{|l|l|l|}
\hline siCONT + TNF- $\alpha$ & $1.00 \pm 0.00$ & $1.00 \pm 0.00$ \\
\hline siRIP1 + TNF- $\alpha$ & $0.41 \pm 0.07^{*}$ & $0.28 \pm 0.12^{*}$ \\
\hline & & \\
\hline siCONT & $0.05 \pm 0.03^{*}$ & $0.03 \pm 0.01^{*}$ \\
\hline siCONT + TNF- $\alpha$ & $1.00 \pm 0.00$ & $1.00 \pm 0.00$ \\
\hline siTAK1 + TNF- $\alpha$ & $0.23 \pm 0.09^{*}$ & $0.09 \pm 0.03^{*}$ \\
\hline
\end{tabular}

For all data, the fold change was calculated relative to TNF- $\alpha$-stimulated siCONT transfected cells, and displayed as mean \pm SEM.

$* P<0.05$ vs. TNF- $\alpha$-stimulated siCONT transfected cells (one-way ANOVA).

\section{FIGURE LEGENDS}

Figure 1. Effect of siTRADD, siTRAF2, siRIP1 and siTAK1 on pro-inflammatory cytokines and chemokines.

Human primary myometrial cells were transfected with (A-F) $50 \mathrm{nM}$ siTRADD, $50 \mathrm{nM}$ siTRAF2 or $50 \mathrm{nM}$ siCONT, (G-L) $100 \mathrm{nM}$ siRIP1 or $100 \mathrm{nM}$ siCONT, or (M-R) $50 \mathrm{nM}$ siTAK1 or $50 \mathrm{nM}$ siCONT for $48 \mathrm{~h}$ and then treated with $10 \mathrm{ng} / \mathrm{ml} \mathrm{TNF-} \alpha$ for an additional $24 \mathrm{~h}$ ( $\mathrm{n}=5$ patients).

(A,C,E,G,I,K,M,O,Q) IL-6, IL-8 and MCP-1 mRNA expression was analysed by qRT-PCR. (B,D,F,H,J,L, N,P,R) IL-6, IL-8 and MCP-1 concentration in the incubation medium was assayed by ELISA. For all data, the fold change was calculated relative to TNF- $\alpha$-stimulated siCONT transfected cells, and displayed as mean \pm SEM. $* P<0.05$ vs. TNF- $\alpha$-stimulated siCONT transfected cells (one-way ANOVA).

Figure 2. Effect of siTRADD, siTRAF2, siRIP1 and siTAK1 on the COX-2-prostaglandin pathway.

Human primary myometrial cells were transfected with (A-C) $50 \mathrm{nM}$ siTRADD, $50 \mathrm{nM}$ siTRAF2 or $50 \mathrm{nM}$ siCONT, (D-F) $100 \mathrm{nM}$ siRIP1 or $100 \mathrm{nM}$ siCONT, or (G-I) $50 \mathrm{nM}$ siTAK1 or $50 \mathrm{nM}$ siCONT for $48 \mathrm{~h}$ and then treated with $10 \mathrm{ng} / \mathrm{ml} \mathrm{TNF}-\alpha$ for an additional $24 \mathrm{~h}$ ( $\mathrm{n}=5$ patients). (A,B,D,E,G,H) COX-2 and FP mRNA expression was analysed by qRT-PCR. (C,F,I) PGF $2 \alpha$ concentration in the incubation medium was assayed by ELISA. For all data, the fold change was calculated relative to TNF- $\alpha$-stimulated siCONT transfected cells, and displayed as mean \pm SEM. $* P<0.05$ vs. TNF- $\alpha$-stimulated siCONT transfected cells (one-way ANOVA). 
Figure 3. Effect of siTRADD, siTRAF2, siRIP1 and siTAK1 on the expression and secretion of adhesion molecules.

Human primary myometrial cells were transfected with (A-D) $50 \mathrm{nM}$ siTRADD, $50 \mathrm{nM}$ siTRAF2 or $50 \mathrm{nM}$ siCONT, (E-H) $100 \mathrm{nM}$ siRIP1 or $100 \mathrm{nM}$ siCONT, or (I-L) $50 \mathrm{nM}$ siTAK1 or $50 \mathrm{nM}$ siCONT for $48 \mathrm{~h}$ and then treated with $10 \mathrm{ng} / \mathrm{ml} \mathrm{TNF}-\alpha$ for an additional $24 \mathrm{~h}$ ( $\mathrm{n}=5$ patients).

(A,C,E,G,I,K) ICAM-1 and VCAM-1 mRNA expression was analysed by qRT-PCR.

(B,D,F,H,J,L) sICAM-1 and sVCAM-1 concentrations in the incubation media was assayed by ELISA. For all data, the fold change was calculated relative to TNF- $\alpha$-stimulated siCONT transfected cells and data displayed as mean \pm SEM. $* P<0.05$ vs. TNF- $\alpha$-stimulated siCONT transfected cells (one-way ANOVA).

Figure 4. Effect of siTRADD, siTRAF2, siRIP1 and siTAK1 on the expression and secretion of MMP-9 expression.

Human primary myometrial cells were transfected with (A,B) $50 \mathrm{nM}$ siTRADD, $50 \mathrm{nM}$ siTRAF2 or $50 \mathrm{nM}$ siCONT, (C,D) $100 \mathrm{nM}$ siRIP1 or $100 \mathrm{nM}$ siCONT, or (E,F) $50 \mathrm{nM}$ siTAK1 or $50 \mathrm{nM}$ siCONT for $48 \mathrm{~h}$ and then treated with $10 \mathrm{ng} / \mathrm{ml}$ TNF- $\alpha$ for an additional $24 \mathrm{~h}$ ( $\mathrm{n}=5$ patients).

(A,C,E) MMP-9 mRNA expression was analysed by qRT-PCR. (B,D,F) The incubation medium was assayed for pro MMP-9 expression by gelatin zymography. Representative zymography image from 1 patient is shown. For all data, the fold change was calculated relative to TNF- $\alpha$-stimulated siCONT transfected cells and data displayed as mean \pm SEM. $* P<0.05$ vs. TNF- $\alpha$-stimulated siCONT transfected cells (one-way ANOVA).

Figure 5. Effect of siTRADD, siTRAF2, siRIP1 and siTAK1 on NF-KB activation.

Human myometrial cells were transfected with $300 \mathrm{ng} / \mathrm{ml} \mathrm{NF- \kappa B}$ reporter construct. After $6 \mathrm{~h}$, cells were transfected with (A) $50 \mathrm{nM}$ siTRADD or $50 \mathrm{nM}$ siCONT, (B) $50 \mathrm{nM}$ siTRAF2 or $50 \mathrm{nM}$ siCONT, (C) $100 \mathrm{nM}$ siRIP1 or $100 \mathrm{nM}$ siCONT, or (D) $50 \mathrm{nM}$ siTAK1 or $50 \mathrm{nM}$ siCONT for 48 $\mathrm{h}$, then treated with $10 \mathrm{ng} / \mathrm{ml} \mathrm{TNF}-\alpha$ for an additional $20 \mathrm{~h}$ (n=5 patients). Promoter activity is expressed as a ratio of luciferase activity of TNF- $\alpha$ stimulated siCONT transfected cells. All data displayed as mean \pm SEM. $* P<0.05$ vs. TNF- $\alpha$-stimulated siCONT transfected cells (one-way ANOVA).

This article is protected by copyright. All rights reserved 
Figure 1
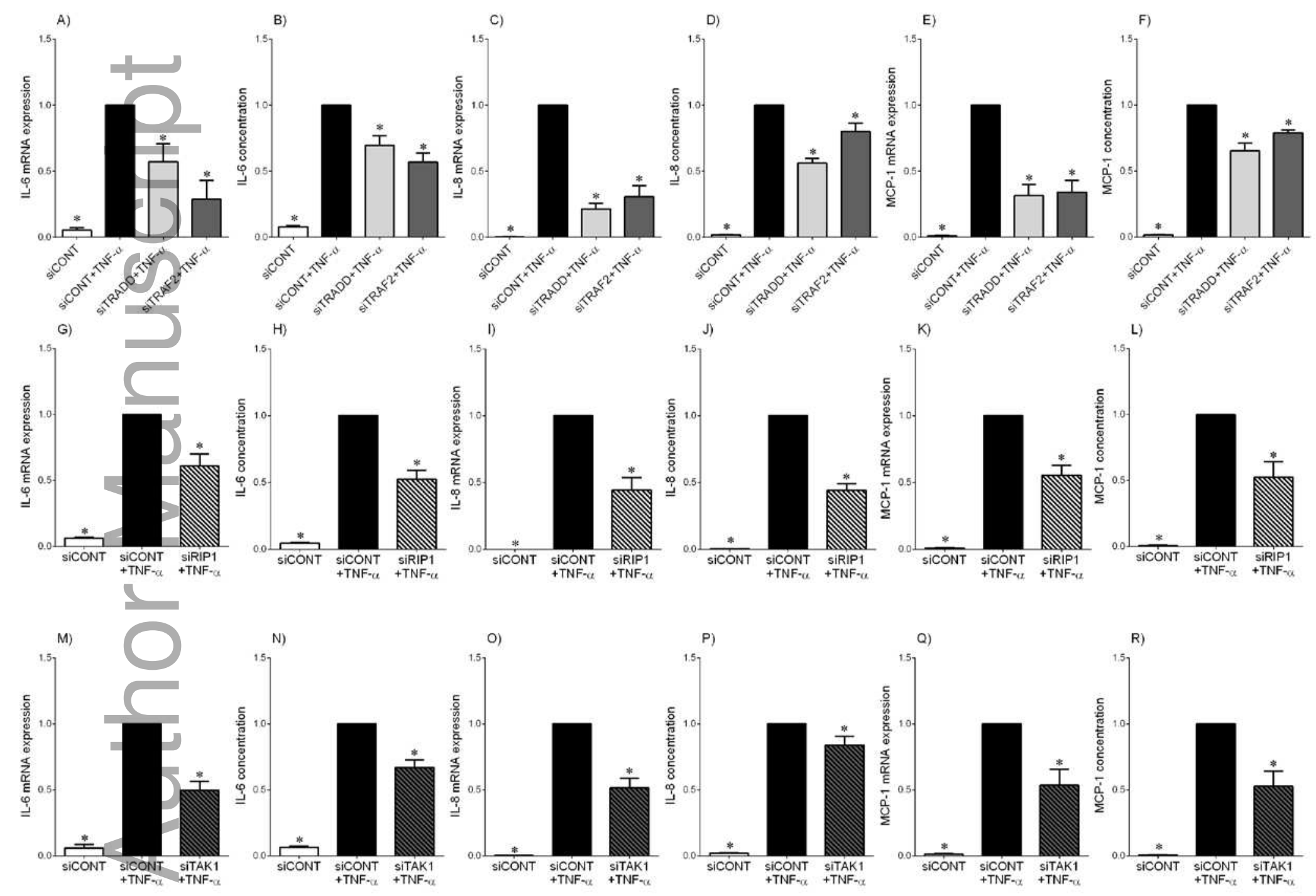
Figure 2

A)

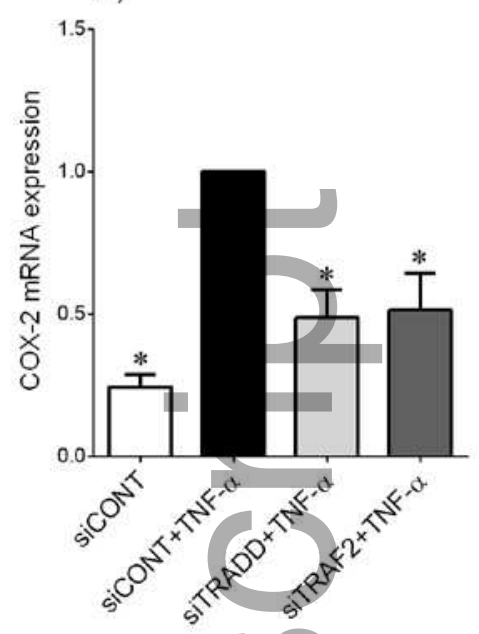

D)

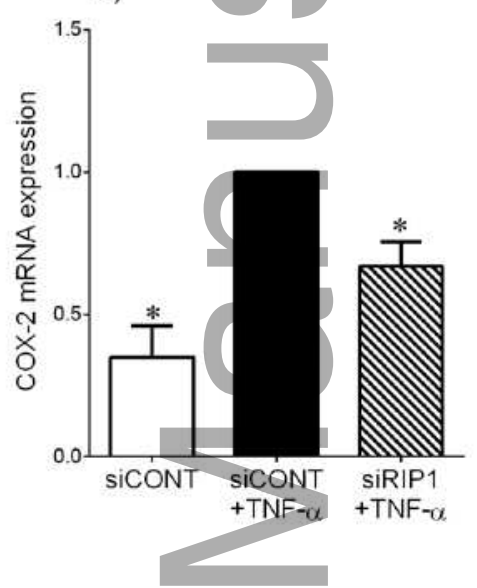

G)

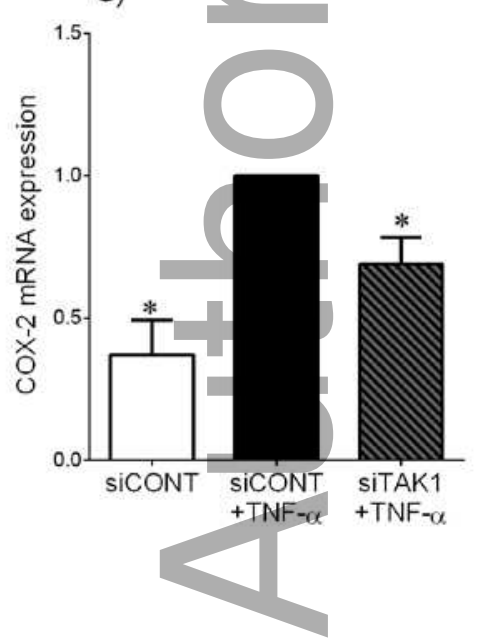

B)

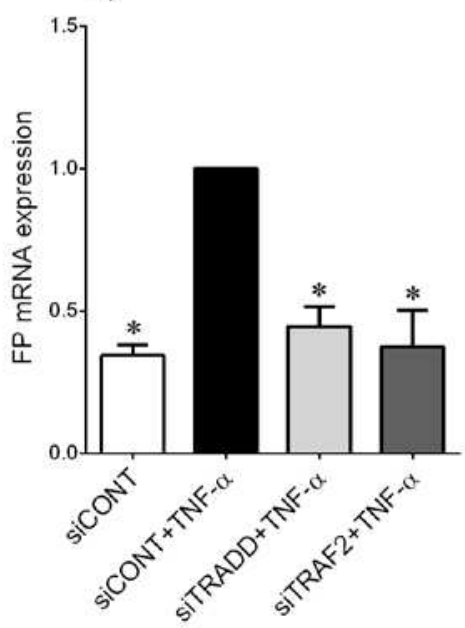

E)

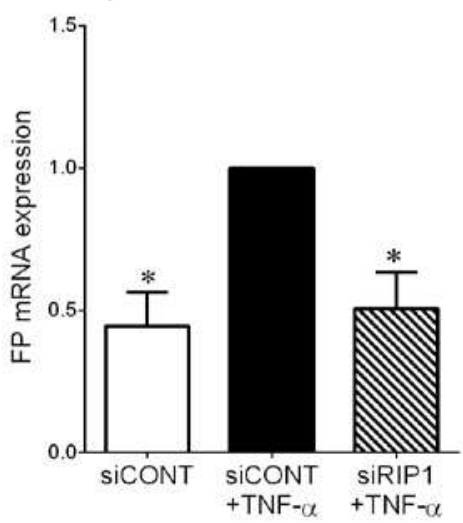

H)

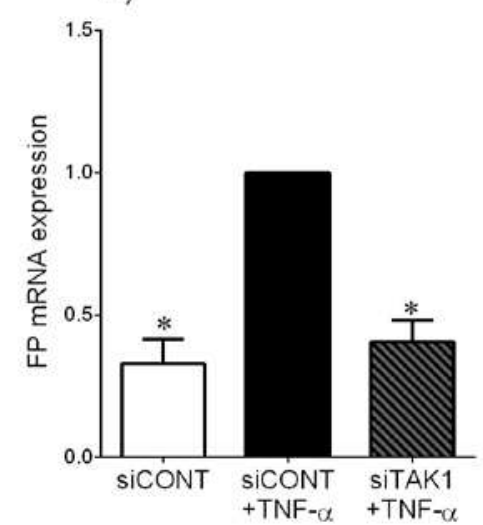

C)

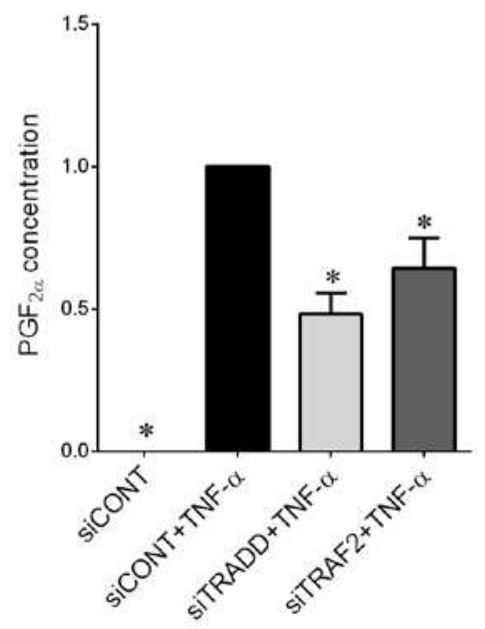

F)
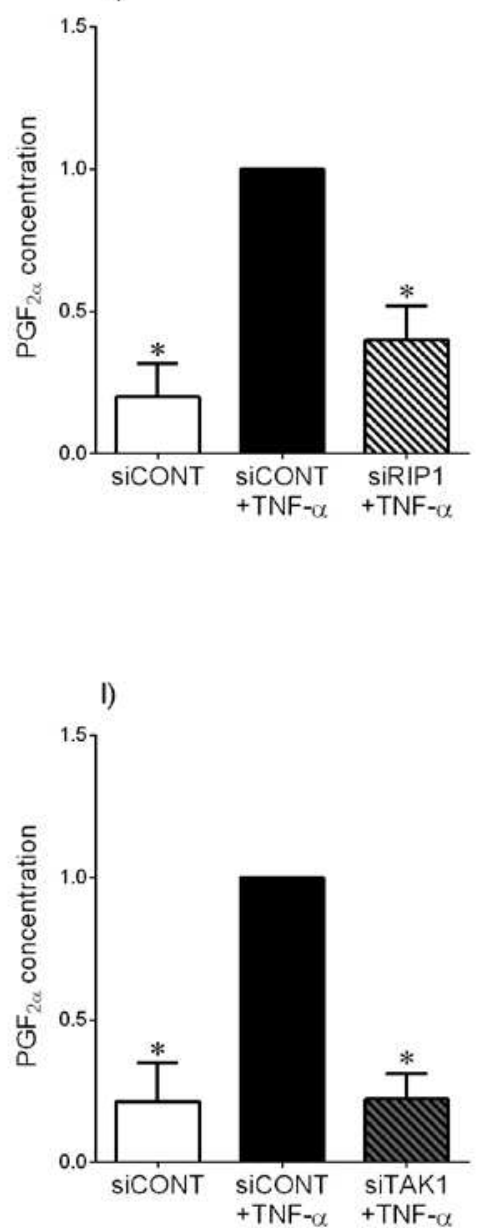
Figure 3
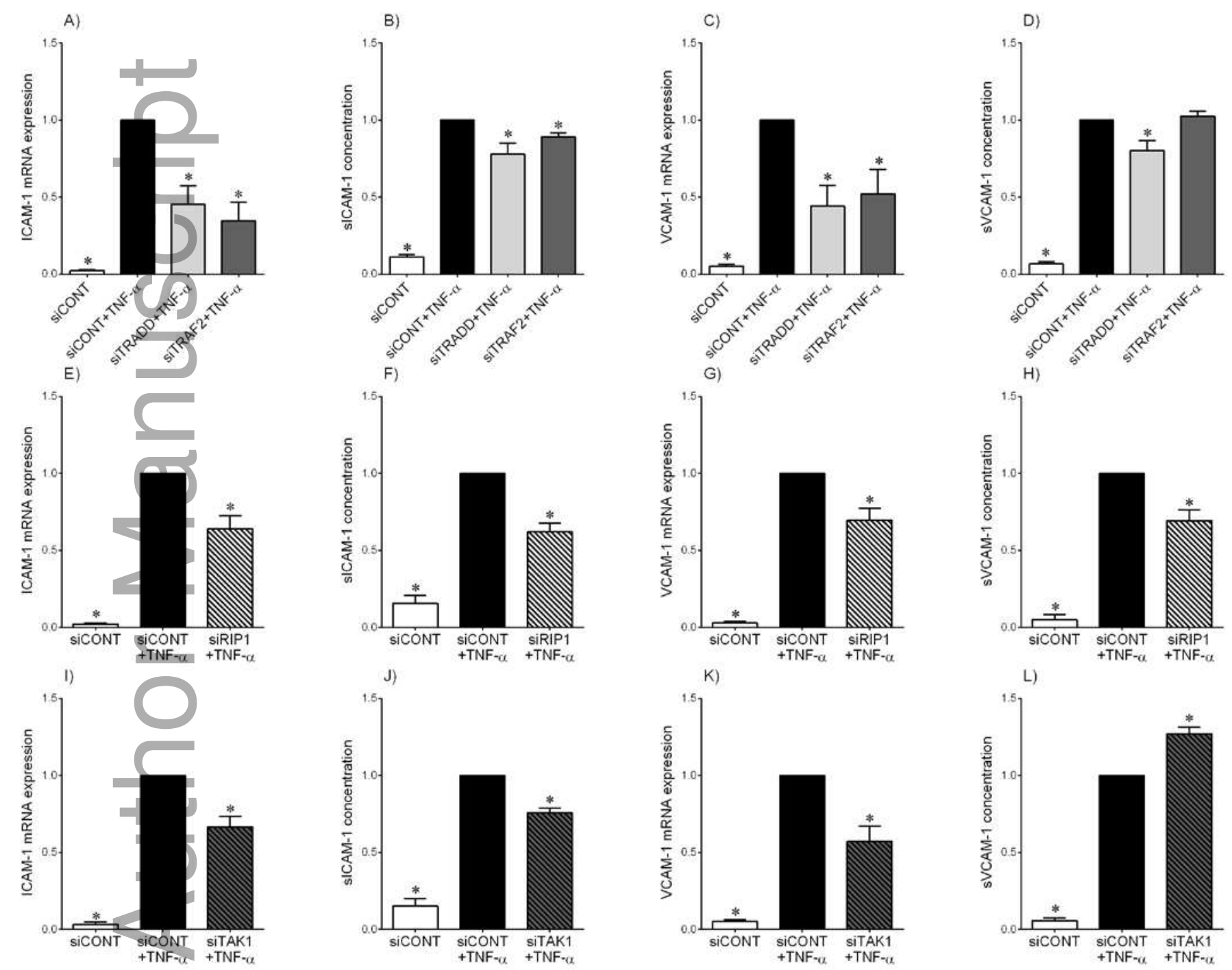


\section{Figure 4}

A)

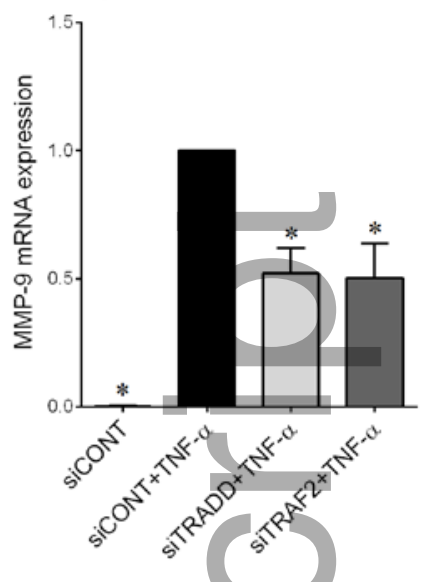

C)

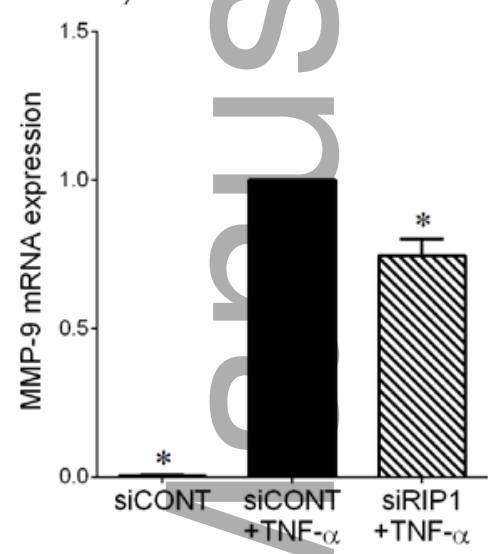

E)

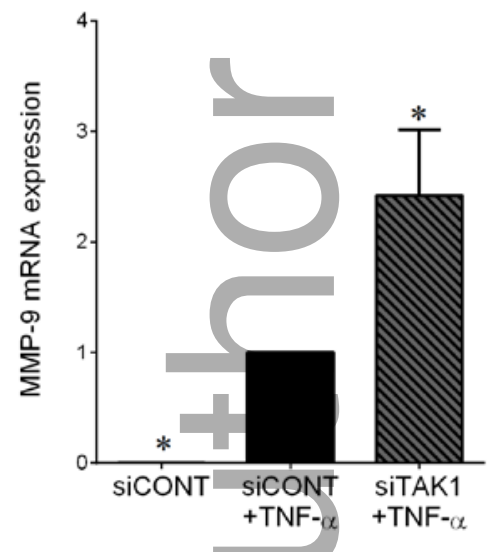

B)

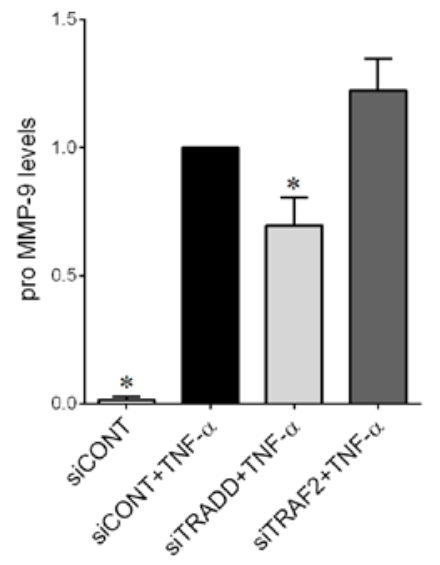

D)

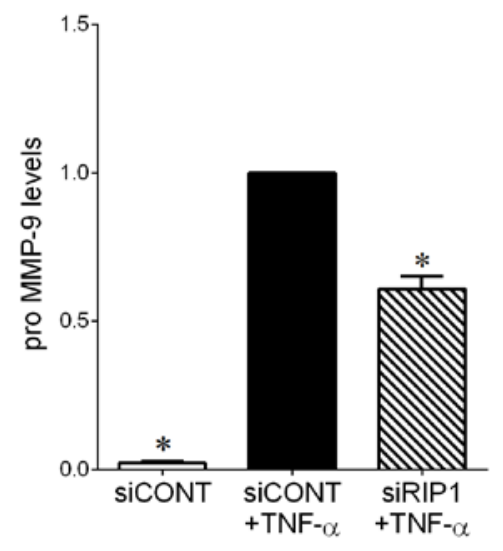

F)

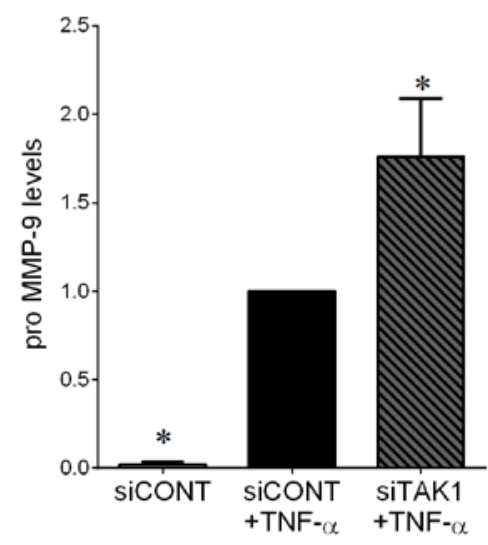

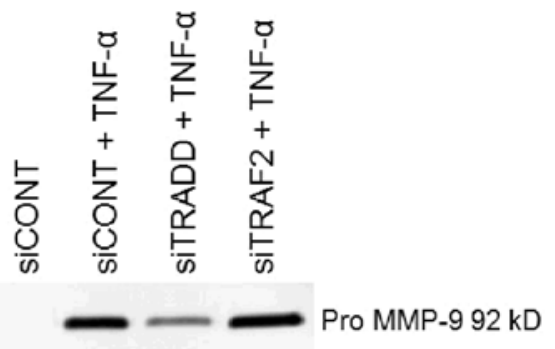

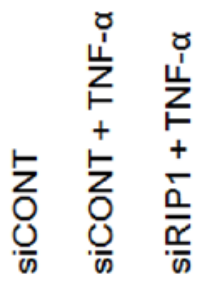

Pro MMP_9 92 kD

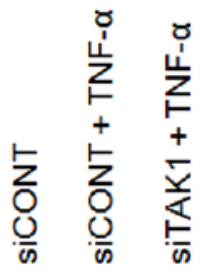

Figure 5 
A)

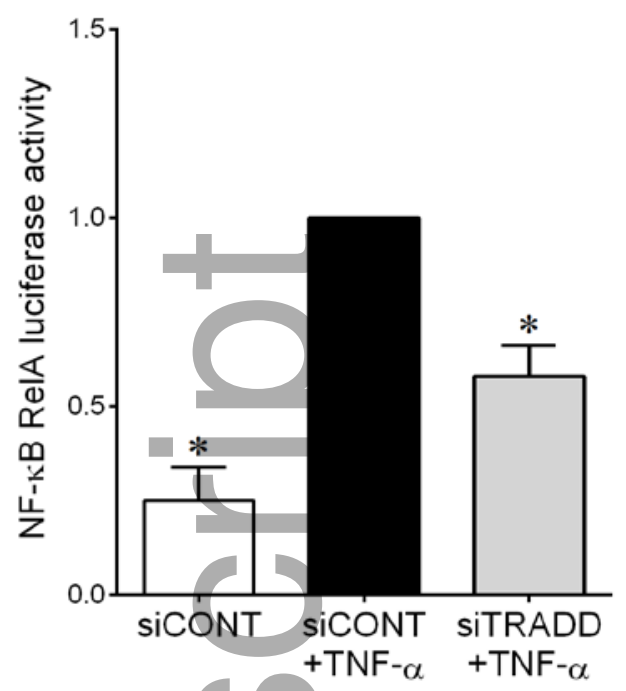

C)

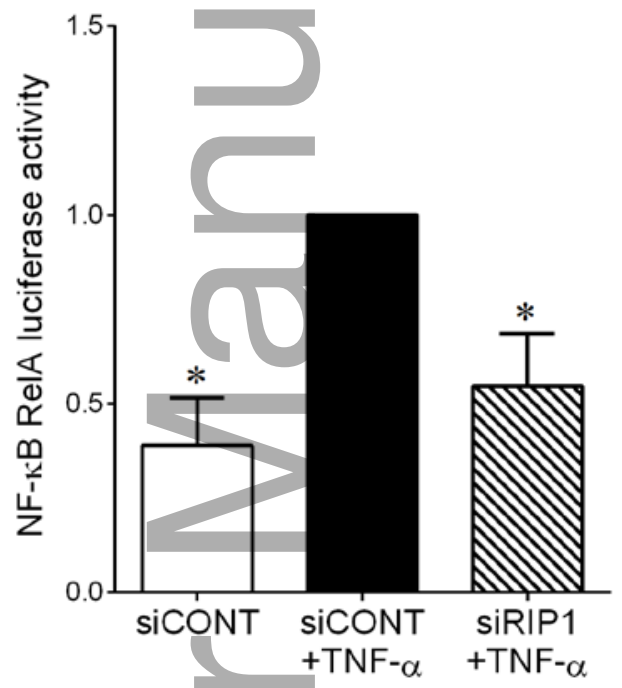

B)

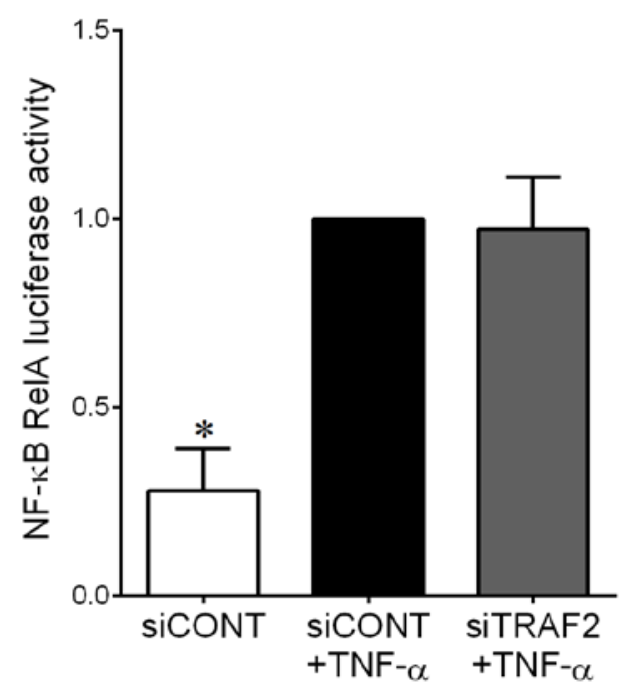

D)

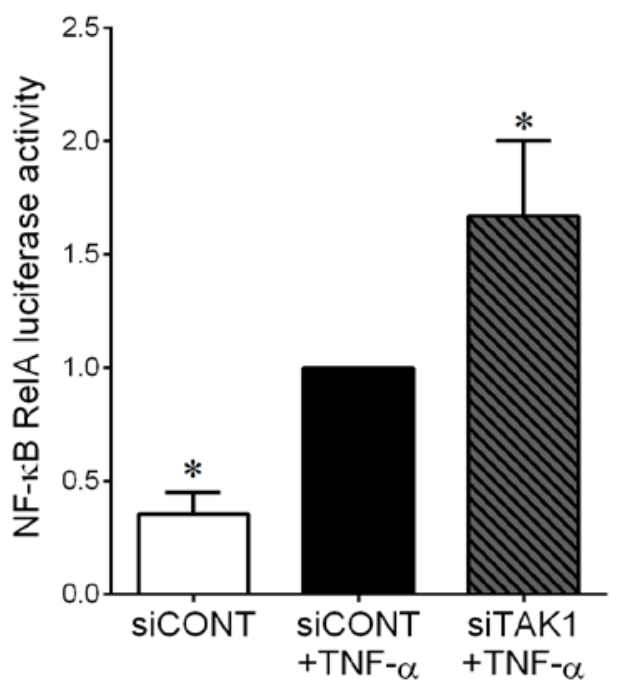




\section{University Library}

\section{- M M N E R VA A gateway to Melbourne's research publications}

Minerva Access is the Institutional Repository of The University of Melbourne

Author/s:

Lim, R;Barker, G;Lappas, M

Title:

TRADD, TRAF2, RIP1 and TAK1 are required for TNF--induced pro-labour mediators in human primary myometrial cells

Date:

2017-07-01

Citation:

Lim, R., Barker, G. \& Lappas, M. (2017). TRADD, TRAF2, RIP1 and TAK1 are required for TNF--induced pro-labour mediators in human primary myometrial cells. AMERICAN JOURNAL OF REPRODUCTIVE IMMUNOLOGY, 78 (1), https://doi.org/10.1111/aji.12664.

Persistent Link:

http://hdl.handle.net/11343/292701 